\title{
A Higher Ratio of Serum Calcium to Magnesium Is Associated With Aggressive Clinicopathological Characteristics in the Patients Who Underwent Radical Prostatectomy
}

\author{
Sang Won Kim, You Jin Lee, Jae-Wook Chung, Yun-Sok Ha, \\ Seock Hwan Choi, Jun Nyung Lee, Bum Soo Kim, Hyun Tae Kim, \\ Tae-Hwan Kim, Eun Sang Yoo, Tae Gyun Kwon
}

Department of Urology, School of Medicine, Kyungpook National University, Daegu, Korea

\begin{abstract}
Purpose: Changes in magnesium $(\mathrm{Mg})$ concentration and calcium-to-magnesium ratio $(\mathrm{Ca} / \mathrm{Mg})$ play a critical role in cancer cell proliferation. In this study, we evaluated the association between preoperative $\mathrm{Ca} / \mathrm{Mg}$ ratio and clinicopathological characteristics of prostate cancer.

Materials and Methods: Preoperative serum levels of $\mathrm{Ca}$ and $\mathrm{Mg}$, as well as the $\mathrm{Ca} / \mathrm{Mg}$ ratio, were retrospectively analyzed in 319 consecutive patients with prostate cancer who underwent radical prostatectomy at our institution between February 2014 and June 2016. Blood Ca and Mg levels, together with the Ca/Mg ratio, were analyzed in relation to the patients' demographic and clinicopathological characteristics.

Results: Preoperative $\mathrm{Ca} / \mathrm{Mg}$ ratio was significantly higher in patients with pathologic Gleason score (pGS) $\geq 8$ than in those with $p G S \leq 7$ (mean [95\% confidence interval]: 4.45 [4.35-4.56] vs. 4.32 [4.27-4.38], $p=0.037$ ). The $\mathrm{Ca} / \mathrm{Mg}$ ratio was positively correlated with preoperative prostate-specific antigen (PSA) levels $(r=0.116, p=0.039)$ and PSA density $(r=0.156, p=0.005)$. Ca/Mg ratio was a preoperative predictor of high $p G S(\geq 8)$ according to multiple logistic regression analysis (odds ratio, 1.752; $95 \%$ confidence interval, 1.002-3.064; $p=0.049$ ).

Conclusions: A high serum $\mathrm{Ca} / \mathrm{Mg}$ ratio was closely associated with worse clinicopathological parameters (high PSA and PSA density and $p G S \geq 8$ ), suggesting that the Ca/Mg ratio may be a useful serological marker for further characterization of oncologic features in prostate cancer. A multicenter prospective study with long-term follow-up is recommended to further assess the utility of this cost-effective marker as a prognostic indicator of prostate cancer. (Korean J Urol Oncol 2018;16:25-31)
\end{abstract}

Key Words: Calcium $\cdot$ Magnesium $\cdot$ Prostatic neoplasms

Received January 8, 2018, Revised February 19, 2018,

Accepted February 21, 2018

Corresponding Author: Hyun Tae Kim

Department of Urology, Kyungpook National University Chilgok

Hospital, 807 Hoguk-ro, Buk-gu, Daegu 41404, Korea

E-mail: ht-kim1212@hanmail.net

Tel: +82-53-200-3027, Fax: +82-53-200-2027

ORCID code: https://orcid.org/0000-0002-4730-3776

- This work was supported by the National Research Foundation of Korea (NRF) grant funded by the Korea government (MSIP) (No. 2016R1C1B1011180).

\section{INTRODUCTION}

In Korea, prostate cancer (PCa) is the most common malignancy of the genitourinary tract and the fifth most common type of cancer among men. ${ }^{1}$ Approximately 11,062 new PCa cases and 1,862 PCa-related deaths occurred in Korea in 2016, and PCa had an age-adjusted mortality rate of 28.0 deaths per 100,000 cases. $^{3}$ Several aspects, including environmental factors, changes in dietary habits, medical advances in laboratory

(c) (F) This is an Open Access article distributed under the terms of the Creative Commons Attribution Non-Commercial License (http://creativecommons.org/licenses/by-nc/4.0/) which permits unrestricted non-commercial use, distribution, and reproduction in any medium, provided the original work is properly cited. 2018 (C) Copyright The Korean Urological Oncology Society and The Korean Prostate Society. All Rights Reserved. 
diagnosis, and campaigns for prostate-specific antigen (PSA) screening, are associated with the increased incidence of PCa. ${ }^{4,5}$ In the United States, PCa is the most prevalent cancer among men and the second leading cause of cancer-related mortality. ${ }^{6}$ Contemporary guidelines recommend that treatment decisions should be based on tumor features, baseline PSA levels, patient age, comorbidity, life expectancy, and quality of life. ${ }^{7}$

Calcium (Ca)-magnesium ( $\mathrm{Mg}$ ) imbalance is implicated in $\mathrm{PCa}^{8}$ Two recent studies found that high serum $\mathrm{Ca}$ levels are associated with aggressive lesions or fatal $\mathrm{PCa} .{ }^{9,10}$ Furthermore, Dai et al. ${ }^{11}$ showed that low blood $\mathrm{Mg}$ levels and a high $\mathrm{Ca} / \mathrm{Mg}$ ratio were significantly associated with high-grade $\mathrm{PCa}$ (Gleason score $\geq 7$ ). In Western countries, intake of dietary $\mathrm{Mg}$ is often lower than the recommended amount of $6 \mathrm{mg} / \mathrm{kg} /$ day. ${ }^{12}$ The 1999-2000 National Health and Nutrition Examination Survey found that $79 \%$ of American adults have an $\mathrm{Mg}$ intake below the Recommended Dietary Allowance. ${ }^{13}$ In Korean adult men, over half of population showed intakes of magnesium less than the estimated average requirement. ${ }^{14}$ Inadequate calcium intake was common. According to the 2013 National Health and Nutrition Survey, calcium intake is only $70 \%$ of the recommendation. Especially in elderly people over 65 years old. ${ }^{15}$ However, a relationship between $\mathrm{Ca} / \mathrm{Mg}$ ratio and $\mathrm{PCa}$ aggressiveness has not yet been established in Asian men. Therefore, we investigated the potential relationship of serum $\mathrm{Ca}$ levels, $\mathrm{Mg}$ levels, and $\mathrm{Ca} / \mathrm{Mg}$ ratio with clinical variables, such as age, demographics, PSA levels, and clinicopathological parameters, in patients who underwent radical prostatectomy.

\section{MATERIALS AND METHODS}

We retrospectively reviewed prospectively maintained data of 319 patients who underwent radical prostatectomy between February 2014 and June 2016 and were histologically confirmed to have PCa. The Ethics Committee of Kyungpook National University Medical Center approved the study protocol (approval number: KNUMC 2017-03-036). The collection and analysis of all samples was approved by the Institutional Review Board of Kyungpook National University Medical Center. Age, body mass index, European Cooperative Oncology Group (ECOG) performance status (PS), drinking status, smoking status, hypertension, diabetes mellitus (DM), preoperative PSA levels, PSA density, biopsy findings, pathologic Gleason score (pGS), PCa stage (TNM classification), and blood levels of $\mathrm{Ca}$ and $\mathrm{Mg}$ were obtained from the medical charts. $\mathrm{Ca}, \mathrm{Mg}$, and the $\mathrm{Ca} / \mathrm{Mg}$ ratio were entered into the analysis as potential predictors and were assessed in relation to the patients' demographic and clinicopathological characteristics.

The $t$-test and analysis of variance test with post hoc analyses were used to compare the Ca levels, $\mathrm{Mg}$ levels, and $\mathrm{Ca} / \mathrm{Mg}$ ratio on stratification according to various clinical parameters. Correlations between $\mathrm{Ca} / \mathrm{Mg}$ ratio and clinicopathological variables, including age, PSA levels, and PSA density, were assessed. Multiple linear regression analysis was performed to evaluate independent variables that influence high pGS $(\geq 8)$. Differences with $\mathrm{p}<0.05$ were considered statistically significant. IBM SPSS ver. 18.0 (IBM Co., Armonk, NY, USA) was used for statistical analyses.

\section{RESULTS}

\section{Baseline characteristics}

The mean age, serum $\mathrm{Ca}$ levels, $\mathrm{Mg}$ levels, and $\mathrm{Ca} / \mathrm{Mg}$ ratio were $66.25 \pm 6.34$ years, $9.43 \pm 0.50 \mathrm{ng} / \mathrm{mL}, 2.18 \pm 0.20 \mathrm{ng} / \mathrm{mL}$, and $4.36 \pm 0.46$, respectively. The mean body mass index was $24.08 \pm 3.06 \mathrm{~kg} / \mathrm{m}^{2}$.

\section{1) $\mathrm{Mg}$ levels, $\mathrm{Ca}$ levels, and $\mathrm{Ca} / \mathrm{Mg}$ ratio according to demographics}

On stratification of patients into four groups according to age ( $<60,60-64,65^{-69}$, and $\geq 70$ years), we found that the Ca levels and $\mathrm{Ca} / \mathrm{Mg}$ ratio were significantly lower, whereas $\mathrm{Mg} \mathrm{lev-}$ els were higher in older patients than in younger patients. $\mathrm{Mg}$ levels were lower in patients with ECOG PS 1 than in those with ECOG status $0(p=0.021)$ and in patients with DM than in those without $\mathrm{DM}(\mathrm{p}<0.001)$. Meanwhile, the $\mathrm{Ca} / \mathrm{Mg}$ ratio was higher in patients with DM than in those without DM (p $<0.001$ ). No significant differences in $\mathrm{Ca} / \mathrm{Mg}$ ratio were noted on stratification of patients according to body mass index, ECOG status, drinking status, smoking status, or history of hypertension (Table 1).

2) $\mathrm{Mg}$ levels, $\mathrm{Ca}$ levels, and the $\mathrm{Ca} / \mathrm{Mg}$ ratio according to preoperative and postoperative clinicopathological factors

The $\mathrm{Ca} / \mathrm{Mg}$ ratio was significantly higher in patients with PSA levels of $>20 \mathrm{ng} / \mathrm{mL}$ than in those with $0-4 \mathrm{ng} / \mathrm{mL}$ ( $\mathrm{p}=0.043$ ) and in patients with $\mathrm{pGS} \geq 8$ than in those with pGS $\leq 7$ (mean [95\% confidence interval]: 4.45 [4.35-4.56] vs. 4.32 
Table 1. Association between calcium (Ca), magnesium $(\mathrm{Mg})$, and $\mathrm{Ca} / \mathrm{Mgratio}$ with study population demographics

\begin{tabular}{|c|c|c|c|c|c|c|c|c|c|c|}
\hline \multirow{2}{*}{ Variable } & \multirow{2}{*}{ No. } & \multicolumn{2}{|c|}{$\mathrm{Ca}$} & \multirow{2}{*}{$\mathrm{p}$-value } & \multicolumn{2}{|c|}{$\mathrm{Mg}$} & \multirow{2}{*}{ p-value } & \multicolumn{2}{|c|}{$\mathrm{Ca} / \mathrm{Mg}$} & \multirow{2}{*}{ p-value } \\
\hline & & Mean & $95 \% \mathrm{CI}$ & & Mean & $95 \% \mathrm{CI}$ & & Mean & $95 \%$ CI & \\
\hline Age (yr) & & & & 0.099 & & & 0.059 & & & 0.004 \\
\hline$<60$ & 49 & 9.57 & $9.43-9.71$ & $0.044^{*}$ & 2.14 & $2.08-2.2$ & $0.021^{\dagger}$ & 4.53 & $4.37-4.68$ & $<0.001^{\dagger}$ \\
\hline $60-64$ & 58 & 9.47 & $9.37-9.56$ & & 2.19 & $2.13-2.24$ & & 4.37 & $4.25-4.48$ & \\
\hline $65-69$ & 106 & 9.40 & $9.3-9.5$ & $0.018^{\dagger}$ & 2.16 & $2.12-2.19$ & $0.027^{\ddagger}$ & 4.40 & $4.3-4.49$ & $0.019^{\ddagger}$ \\
\hline$\geq 70$ & 106 & 9.37 & $9.27-9.47$ & & 2.22 & $2.18-2.25$ & & 4.25 & $4.18-4.32$ & \\
\hline BMI $\left(\mathrm{kg} / \mathrm{m}^{2}\right)$ & & & & 0.241 & & & 0.256 & & & 0.589 \\
\hline$<23$ & 101 & 9.36 & $9.27-9.45$ & & 2.17 & $2.13-2.2$ & & 4.36 & $4.27-4.45$ & \\
\hline $23-27.4$ & 185 & 9.46 & $9.39-9.54$ & & 2.19 & $2.16-2.22$ & & 4.35 & $4.28-4.42$ & \\
\hline$\geq 27.5$ & 33 & 9.45 & $9.26^{-9.64}$ & & 2.14 & $2.08-2.19$ & & 4.44 & $4.31-4.57$ & \\
\hline ECOG PS & & & & 0.369 & & & 0.021 & & & 0.216 \\
\hline 0 & 165 & 9.45 & $9.38-9.53$ & & 2.20 & $2.17-2.24$ & & 4.33 & $4.25-4.41$ & \\
\hline 1 & 154 & 9.40 & $9.32-9.48$ & & 2.15 & $2.12-2.18$ & & 4.40 & $4.33-4.46$ & \\
\hline Drinking & & & & 0.529 & & - & 0.026 & & - & 0.081 \\
\hline No & 222 & 9.42 & $9.35-9.48$ & & 2.16 & $2.14-2.19$ & & 4.39 & $4.33-4.45$ & \\
\hline Yes & 97 & 9.46 & $9.35-9.56$ & & 2.22 & $2.18-2.25$ & & 4.29 & $4.21-4.38$ & \\
\hline Smoking & & & & 0.610 & & & 0.568 & & & 0.395 \\
\hline No & 191 & 9.42 & $9.36^{-9.48}$ & & 2.19 & $2.16-2.21$ & & 4.33 & $4.28-4.39$ & \\
\hline Current & 49 & 9.49 & $9.33-9.66$ & & 2.18 & $2.1-2.26$ & & 4.42 & $4.24-4.59$ & \\
\hline Quit & 79 & 9.41 & $9.29-9.54$ & & 2.16 & $2.11-2.2$ & & 4.40 & $4.29-4.5$ & \\
\hline Hypertension & & & & 0.147 & & & 0.616 & & & 0.112 \\
\hline No & 178 & 9.39 & $9.32-9.47$ & & 2.18 & $2.16-2.21$ & & 4.33 & $4.27-4.38$ & \\
\hline Yes & 141 & 9.47 & $9.4-9.55$ & & 2.17 & $2.14-2.21$ & & 4.41 & $4.32-4.5$ & \\
\hline Diabetes & & & & 0.869 & & & $<0.001$ & & & $<0.001$ \\
\hline No & 270 & 9.43 & $9.37-9.49$ & & 2.20 & $2.18-2.23$ & & 4.31 & $4.26-4.36$ & \\
\hline Yes & 49 & 9.42 & $9.28-9.56$ & & 2.05 & $2-2.1$ & & 4.63 & $4.47-4.8$ & \\
\hline
\end{tabular}

CI: confidence interval, BMI: body mass index, ECOG PS: European Cooperative Oncology Group Performance Status. $*<60$ years vs. $65-69$ years. ${ }^{\dagger}<60$ years vs. $\geq 70$ years. ${ }^{\dagger} 65-69$ years vs. $\geq 70$ years.

[4.27-4.38], p=0.037). Finally, Ca levels differed significantly between patients with clinical stage $\leq \mathrm{T} 2$ and those with clinical stage $\geq \mathrm{T} 3$ ( $\mathrm{p}=0.020$ ), whereas $\mathrm{Mg}$ levels differed significantly between patients with pathologic stage N0/x and those with stage $\geq \mathrm{N} 1 \quad(\mathrm{p}=0.024)$ (Table 2).

\section{3) Correlations between $\mathrm{Ca} / \mathrm{Mg}$ ratio and clinicopathological parameters}

Blood Ca levels were significantly associated with PSA levels and PSA density. The $\mathrm{Ca} / \mathrm{Mg}$ ratio was positively correlated with preoperative PSA levels $(r=0.116, p=0.039)$ and PSA density $(\mathrm{r}=0.156, \mathrm{p}=0.005)$ (Table 3$)$.

\section{4) Multivariate analysis of preoperative predictors of high Gleason score $(\geq 8)$}

In multivariable modeling, preoperative PSA (odds ratio [OR], 1.026; 95\% confidence interval [CI], 1.008-1.044, $\mathrm{p}=0.004)$ and $\mathrm{Ca} / \mathrm{Mg}$ (OR, 1.752; 95\% CI, 1.002-3.064, $\mathrm{p}=0.049)$ were associated with high Gleason score $(\geq 8)$ adjusted for age and BMI (Table 4).

\section{DISCUSSION}

In the present study, we investigated the potential of $\mathrm{Ca}, \mathrm{Mg}$, and $\mathrm{Ca} / \mathrm{Mg}$ ratio as biomarkers for identifying high-grade $\mathrm{PCa}$. Our analysis indicated that relatively high $\mathrm{Ca}$ levels and low $\mathrm{Mg}$ levels, albeit at subclinical limits, can predict more aggressive $\mathrm{PCa}$. Moreover, the $\mathrm{Ca} / \mathrm{Mg}$ ratio was positively correlated with preoperative PSA levels and PSA density.

$\mathrm{The} \mathrm{Ca} / \mathrm{Mg}$ ratio increases or decreases with cell proliferation or apoptosis, respectively. ${ }^{8}$ Among other metals, $\mathrm{Ca}$ and $\mathrm{Mg}$ concentrations are significantly higher in malignant prostate tumors than in benign prostate tumors. ${ }^{16}$ Additionally, intranuclear Ca levels have increased with aging and is believed to 
Table 2. Relationship of preoperative and postoperative clinicopathological factors with calcium $(\mathrm{Ca})$, magnesium $(\mathrm{Mg})$, and $\mathrm{Ca} / \mathrm{Mg}$ ratio ratio

\begin{tabular}{|c|c|c|c|c|c|c|c|c|c|c|}
\hline \multirow{2}{*}{ Variable } & \multirow{2}{*}{ No. } & \multicolumn{2}{|c|}{$\mathrm{Ca}$} & \multirow{2}{*}{ p-value } & \multicolumn{2}{|c|}{$\mathrm{Mg}$} & \multirow{2}{*}{ p-value } & \multicolumn{2}{|c|}{$\mathrm{Ca} / \mathrm{Mg}$} & \multirow{2}{*}{ p-value } \\
\hline & & Mean & $95 \% \mathrm{CI}$ & & Mean & $95 \% \mathrm{CI}$ & & Mean & $95 \% \mathrm{CI}$ & \\
\hline PSA (ng/mL) & & & & 0.067 & & & 0.401 & & & 0.136 \\
\hline $0-4$ & 43 & 9.26 & $9.17-9.36$ & $0.009 *$ & 2.18 & $2.13-2.24$ & $0.090^{\dagger}$ & 4.27 & $4.16-4.38$ & $0.043^{\dagger}$ \\
\hline $4.1-10$ & 165 & 9.48 & $9.41-9.56$ & & 2.18 & $2.15-2.21$ & & 4.38 & $4.31-4.46$ & \\
\hline $10.1-20$ & 71 & 9.40 & $9.28-9.52$ & & 2.20 & $2.14-2.25$ & & 4.31 & $4.21-4.4$ & \\
\hline$>20$ & 40 & 9.44 & $9.24-9.64$ & & 2.13 & $2.06-2.2$ & & 4.47 & $4.29-4.65$ & \\
\hline Biopsy GS & & & - & 0.287 & & - & 0.305 & & - & 0.056 \\
\hline$\leq 7$ & 228 & 9.41 & $9.35-9.47$ & & 2.19 & $2.16-2.21$ & & 4.33 & $4.28-4.39$ & \\
\hline$\geq 8$ & 91 & 9.48 & $9.36-9.6$ & & 2.16 & $2.11-2.21$ & & 4.44 & $4.33-4.55$ & \\
\hline Clinical $\mathrm{T}$ stage & & & - & 0.020 & & - & 0.630 & & - & 0.122 \\
\hline$\leq \mathrm{T} 2$ & 279 & 9.41 & $9.35-9.46$ & & 2.18 & $2.16-2.2$ & & 4.35 & $4.29-4.4$ & \\
\hline$\geq \mathrm{T} 3$ & 40 & 9.6 & $9.41-9.79$ & & 2.16 & $2.09-2.24$ & & 4.47 & $4.33-4.6$ & \\
\hline Pathologic GS & & & - & 0.416 & & - & 0.070 & & - & 0.037 \\
\hline$\leq 7$ & 226 & 9.41 & $9.35-9.47$ & & 2.19 & $2.17-2.22$ & & 4.32 & $4.27-4.38$ & \\
\hline$\geq 8$ & 93 & 9.47 & $9.35-9.59$ & & 2.15 & $2.1-2.19$ & & 4.45 & $4.35-4.56$ & \\
\hline Pathologic $\mathrm{T}$ stage & & & - & 0.623 & & - & 0.495 & & - & 0.284 \\
\hline$\leq \mathrm{T} 2$ & 174 & 9.42 & $9.35-9.49$ & & 2.19 & $2.16-2.21$ & & 4.34 & $4.28-4.4$ & \\
\hline$\geq \mathrm{T} 3$ & 145 & 9.44 & $9.36^{-9.53}$ & & 2.17 & $2.14-2.21$ & & 4.40 & $4.31-4.48$ & \\
\hline Pathologic N stage & & & - & 0.076 & & - & 0.024 & & - & 0.209 \\
\hline $\mathrm{N} 0 / \mathrm{Nx}$ & 302 & 9.44 & $9.39-9.5$ & & 2.18 & $2.16-2.21$ & & 4.36 & $4.31-4.41$ & \\
\hline N1 & 14 & 9.20 & $8.9-9.5$ & & 2.06 & $1.91-2.2$ & & 4.52 & $4.24-4.79$ & \\
\hline Margin status & & & - & 0.390 & & - & 0.984 & & - & 0.843 \\
\hline Negative & 109 & 9.46 & $9.37-9.55$ & & 2.18 & $2.14-2.21$ & & 4.37 & $4.3-4.44$ & \\
\hline Positive & 210 & 9.41 & $9.34-9.48$ & & 2.18 & $2.15-2.21$ & & 4.36 & $4.29-4.43$ & \\
\hline
\end{tabular}

CI: confidence interval, PSA: prostate-specific antigen, GS: Gleason score.

${ }^{*} 0-4 \mathrm{ng} / \mathrm{mL}$ vs. $4.1-10 \mathrm{ng} / \mathrm{mL} .{ }^{\dagger} 10.1-20 \mathrm{ng} / \mathrm{mL}$ vs. $>20 \mathrm{ng} / \mathrm{mL} .{ }^{\dagger} 0-4 \mathrm{ng} / \mathrm{mL}$ vs. $>20 \mathrm{ng} / \mathrm{mL}$.

Table 3. Correlations between calcium $(\mathrm{Ca})$, magnesium $(\mathrm{Mg})$, and $\mathrm{Ca} / \mathrm{Mg}$ ratio with continuous variables

\begin{tabular}{|c|c|c|c|c|c|c|}
\hline \multirow{2}{*}{ Variable } & \multicolumn{2}{|c|}{$\mathrm{Ca}$} & \multicolumn{2}{|c|}{$\mathrm{Mg}$} & \multicolumn{2}{|c|}{$\mathrm{Ca} / \mathrm{Mg}$ ratio } \\
\hline & $\mathrm{r}$ & $\mathrm{p}$-value & $\mathrm{r}$ & $\mathrm{p}$-value & $\mathrm{r}$ & p-value \\
\hline Age & -0.155 & 0.005 & 0.119 & 0.033 & -0.197 & $<0.001$ \\
\hline Preoperative PSA & 0.114 & 0.041 & -0.053 & 0.349 & 0.116 & 0.039 \\
\hline PSA density & 0.133 & 0.018 & -0.077 & 0.168 & 0.156 & 0.005 \\
\hline
\end{tabular}

PSA: prostate-specific antigen, r: correlation coefficient.

Table 4. Multivariate analysis of preoperative predictors of high Gleason score $(\geq 8)$ according to the multivariate logistic regression analysis

\begin{tabular}{lccc}
\hline \multicolumn{1}{c}{ Variable } & OR & $95 \%$ CI & p-value \\
\hline Age & 1.015 & $0.974-1.057$ & 0.477 \\
BMI & 1.036 & $0.953-1.127$ & 0.403 \\
Preoperative PSA & 1.026 & $1.008-1.044$ & 0.004 \\
Ca/Mg ratio & 1.752 & $1.002-3.064$ & 0.049 \\
\hline
\end{tabular}

OR: odds ratio, CI: confidence interval, BMI: body mass index, PSA: prostate-specific antigen, $\mathrm{Ca}$ : calcium, $\mathrm{Mg}$ : magnesium. have pathologic significance in prostate growth disorders. ${ }^{17}$ High dietary $\mathrm{Ca}$ intake is positively associated with increased risk of PCa. ${ }^{18,19}$ In their prospective, cohort study, Skinner and Schwartz ${ }^{10}$ reported an approximately 3 -fold increase in the risk for fatal PCa among men whose serum $\mathrm{Ca}$ levels are in the upper tertile of the distribution of values for the general population. While such an association had not been previously demonstrated in Korean patients, our present study found that blood Ca levels were significantly associated with PSA levels and density. Moreover, $\mathrm{Ca}$ levels differed significantly with 
clinical $\mathrm{T}$ stage $(\leq \mathrm{T} 2$ vs. $\geq \mathrm{T} 3)$.

$\mathrm{Mg}$ is essential for many biological processes, including the synthesis of organic molecules, cell proliferation, energy production, muscle contraction and relaxation, bone development, mineral metabolism, and glucose homeostasis. ${ }^{20}$ In North America, $\mathrm{Mg}$ intake falls short of dietary recommendations for a large segment of the population. ${ }^{21}$ Low $\mathrm{Mg}$ intake and/or serum $\mathrm{Mg}$ concentrations have been associated with a number of diseases and health conditions, including $\mathrm{DM}^{22}$ breast cancer, ${ }^{23}$ and colorectal cancer. ${ }^{24}$ In agreement with previous studies, our study involving a PCa cohort found that $\mathrm{Mg}$ levels were significantly lower in patients with DM than in those without DM. Furthermore, a population-based prospective study revealed that high $\mathrm{Mg}$ intake may reduce the occurrence of colorectal cancer in women. ${ }^{24}$ Yang et al. ${ }^{25}$ believed that $\mathrm{Mg}$ intake from drinking water and other dietary sources may significantly reduce the risk of PCa development. Dai et al. ${ }^{11}$ showed that low blood $\mathrm{Mg}$ levels and a high $\mathrm{Ca} / \mathrm{Mg}$ ratio were significantly associated with high-grade $\mathrm{PCa}$ (pGS $\geq 7$ ). In agreement with these previous observations, we found that the $\mathrm{Ca} / \mathrm{Mg}$ ratio was significantly higher in patients with $\mathrm{pGS} \geq 8$ than in those with $\mathrm{pGS} \leq 7$. Furthermore, $\mathrm{Mg}$ levels differed significantly with pathologic $\mathrm{N}$ stage ( $\mathrm{N} 0 / \mathrm{x}$ vs. $\geq \mathrm{N} 1)$. $\mathrm{Mg}$ can prevent carcinogenesis through at least 2 biologically possible mechanism, namely that intracellular Mg may enhance the fidelity of DNA replication or prevent changes that trigger the carcinogenic process. ${ }^{26}$ Also, Mg levels differed significantly with ECOG PS (0 vs. 1). Patients with poor ECOG PS are less likely to have dietary intake and lack of essential elements. In addition, malignancy can influence metabolic and physiological changes that affect the patient's nutritional status and required nutrients. ${ }^{27}$ Lower $\mathrm{Mg}$ concentrations affect the carcinogenic pathways of the body, as noted above. As a result, poorer ECOG PS is considered to be a phenotype of disease progression.

In this study, $\mathrm{Ca}$ and $\mathrm{Mg}$ individually showed significant differences in several pathologic characteristics, but did not show a consistent association. The $\mathrm{Ca} / \mathrm{Mg}$ ratio is believed to be more related to aggressiveness of $\mathrm{PCa}$ than to $\mathrm{Ca}$ or $\mathrm{Mg}$ alone. The TRPM7 is regulated by serum $\mathrm{Mg}$ concentrations, which is a magnesium-nucleotide-regulated metal current channel. It is expressed in both PCa and control cells, but is more expressed in PCa cells. The increase of cell proliferation was significantly higher in high $\mathrm{Ca} / \mathrm{Mg}$ group than in control group. ${ }^{8}$ According to this result, it can be assumed that $\mathrm{Ca} / \mathrm{Mg}$ ratio is related to the aggressiveness of the $\mathrm{PCa}$. In addition, $\mathrm{Ca} / \mathrm{Mg}$ ratio was positively correlated with PSA and PSAD.

Choosing an appropriate treatment strategy for PCa primarily depends on the preoperative risk of disease progression. Patients will be offered different treatment options based on the outcomes of risk evaluation. ${ }^{28}$ In counseling, physicians rely mostly on pGS, which is currently the most reliable prognostic marker in PCa. PSA levels and density are also useful biological markers for the management of patients with $\mathrm{PCa}^{29} \mathrm{~A}$ recent study reported the superiority of PSA density over PSA levels for prediction of upgrading among patients with $\mathrm{pGS}=6 .^{30}$ A possible explanation for the predictive superiority of PSA density over PSA levels may involve the effect of prostate size. Specifically, large prostates are more likely to have an enlarged transition zone, which is associated with low incidence of $\mathrm{PCa}$. In this context, the $\mathrm{Ca} / \mathrm{Mg}$ ratio is a useful serological marker for further characterization of oncologic features in patients with $\mathrm{PCa}$.

To the best of our knowledge, the present study is the first to examine and observe a significant relationship between $\mathrm{Ca} / \mathrm{Mg}$ ratio and the aggressiveness of $\mathrm{PCa}$ among patients underwent radical prostatectomy. The major strengths of our study include the prospectively maintained cohort and relatively large sample size (319 patients, albeit from a single center). Our study also has several potential limitations. First, the data were analyzed in a retrospective manner. Because the follow-up period was short, we did not perform survival analysis to analyze recurrence-free survival after surgery. Despite these limitations, our study clearly showed that a high preoperative $\mathrm{Ca} / \mathrm{Mg}$ ratio was associated with a high risk of high-grade $\mathrm{PCa}$, suggesting the interaction between $\mathrm{Mg}$ and $\mathrm{Ca}$, which play a role in the pathogenesis and progression of PCa. These findings, if confirmed, may pave the way for individualized medical treatment or adjuvant care of patients with PCa.

\section{CONCLUSION}

We found that a high $\mathrm{Ca} / \mathrm{Mg}$ ratio was closely associated with worse clinicopathological parameters, such as high PSA levels, high PSA density, and $\mathrm{pGS} \geq 8$. Our results suggest that the $\mathrm{Ca} / \mathrm{Mg}$ ratio may be a useful serological marker for further characterization of the oncologic features of patients with PCa. A multicenter prospective study with long-term follow-up is recommended to further assess the utility of this ubiquitous and 
cost-effective marker as a prognostic indicator of $\mathrm{PCa}$.

\section{CONFLICT OF INTEREST}

The authors claim no conflicts of interest.

\section{REFERENCES}

1. Jung KW, Won YJ, Oh CM, Kong HJ, Lee DH, Lee KH, et al. Cancer statistics in Korea: incidence, mortality, survival, and prevalence in 2014. Cancer Res Treat 2017;49:292-305.

2. Oh CM, Won YJ, Jung KW, Kong HJ, Cho H, Lee JK, et al. Cancer statistics in Korea: incidence, mortality, survival, and prevalence in 2013. Cancer Res Treat 2016;48:436-50.

3. Jung KW, Won YJ, Oh CM, Kong HJ, Cho H, Lee JK, et al. Prediction of cancer incidence and mortality in Korea, 2016. Cancer Res Treat 2016;48:451-7.

4. Chung BH. The role of radical prostatectomy in high-risk prostate cancer. Prostate Int 2013;1:95-101.

5. Ha JY, Shin TJ, Jung W, Kim BH, Park CH, Kim CI. Updated clinical results of active surveillance of very-low-risk prostate cancer in Korean men: 8 years of follow-up. Investig Clin Urol 2017;58:164-70.

6. Siegel RL, Miller KD, Jemal A. Cancer statistics, 2016. CA Cancer J Clin 2016;66:7-30.

7. Heidenreich A, Bastian PJ, Bellmunt J, Bolla M, Joniau S, van der Kwast $\mathrm{T}$, et al. EAU guidelines on prostate cancer. part 1: screening, diagnosis, and local treatment with curative intent-update 2013. Eur Urol 2014;65:124-37.

8. Sun Y, Selvaraj S, Varma A, Derry S, Sahmoun AE, Singh BB. Increase in serum $\mathrm{Ca} 2+/ \mathrm{Mg} 2+$ ratio promotes proliferation of prostate cancer cells by activating TRPM7 channels. J Biol Chem 2013;288:255-63.

9. Skinner HG, Schwartz GG. A prospective study of total and ionized serum calcium and fatal prostate cancer. Cancer Epidemiol Biomarkers Prev 2009;18:575-8.

10. Skinner HG, Schwartz GG. Serum calcium and incident and fatal prostate cancer in the National Health and Nutrition Examination Survey. Cancer Epidemiol Biomarkers Prev 2008; 17:2302-5.

11. Dai Q, Motley SS, Smith JA Jr, Concepcion R, Barocas D, Byerly $S$, et al. Blood magnesium, and the interaction with calcium, on the risk of high-grade prostate cancer. PLoS One 2011;6:e18237.

12. Durlach J. Recommended dietary amounts of magnesium: $\mathrm{Mg}$ RDA. Magnes Res 1989;2:195-203.

13. Ervin RB, Wang CY, Wright JD, Kennedy-Stephenson J. Dietary intake of selected minerals for the United States population: 1999-2000. Adv Data 2004;(341):1-5.

14. Choi MK, Bae YJ. Relationship between dietary magnesium, manganese, and copper and metabolic syndrome risk in Korean adults: the Korea National Health and Nutrition Examination Survey (2007-2008). Biol Trace Elem Res 2013;156:56-66.

15. Lim HS, Park YH, Lee HH, Kim TH, Kim SK. Comparison of calcium intake status by region and socioeconomic status in Korea: The 2011-2013 Korea National Health and Nutrition Examination Survey. J Bone Metab 2015;22:119-26.

16. Yaman M, Atici D, Bakirdere S, Akdeniz I. Comparison of trace metal concentrations in malign and benign human prostate. J Med Chem 2005;48:630-4.

17. Tvedt KE, Halgunset J, Kopstad G, Haugen OA. Intracellular distribution of calcium and zinc in normal, hyperplastic, and neoplastic human prostate: X-ray microanalysis of freeze-dried cryosections. Prostate 1989;15:41-51.

18. Ahn J, Albanes D, Peters U, Schatzkin A, Lim U, Freedman $\mathrm{M}$, et al. Dairy products, calcium intake, and risk of prostate cancer in the prostate, lung, colorectal, and ovarian cancer screening trial. Cancer Epidemiol Biomarkers Prev 2007;16: 2623-30.

19. Aune D, Navarro Rosenblatt DA, Chan DS, Vieira AR, Vieira $\mathrm{R}$, Greenwood DC, et al. Dairy products, calcium, and prostate cancer risk: a systematic review and meta-analysis of cohort studies. Am J Clin Nutr 2015;101:87-117.

20. Bertinato J, Wang KC, Hayward S. Serum magnesium concentrations in the Canadian population and associations with diabetes, glycemic regulation, and insulin resistance. Nutrients 2017 Mar 17;9(3). pii: E296. https://doi.org/10.3390/nu9030296.

21. Ford ES, Mokdad AH. Dietary magnesium intake in a national sample of US adults. J Nutr 2003;133:2879-82.

22. Ziegler D. Type 2 diabetes as an inflammatory cardiovascular disorder. Curr Mol Med 2005;5:309-22.

23. Sartori S, Nielsen I, Tassinari D, Mazzotta D, Vecchiatti G, Sero A, et al. Serum and erythrocyte magnesium concentrations in solid tumours: relationship with stage of malignancy. Magnes Res 1992;5:189-92.

24. Larsson SC, Bergkvist L, Wolk A. Magnesium intake in relation to risk of colorectal cancer in women. JAMA 2005;293: 86-9.

25. Yang CY, Chiu HF, Tsai SS, Cheng MF, Lin MC, Sung FC. Calcium and magnesium in drinking water and risk of death from prostate cancer. J Toxicol Environ Health A 2000;60: 17-26.

26. Blondell JM. The anticarcinogenic effect of magnesium. Med Hypotheses 1980;6:863-71.

27. Vandebroek AJ, Schrijvers D. Nutritional issues in anti-cancer treatment. Ann Oncol 2008;19 Suppl 5:v52-5.

28. Santok GD, Abdel Raheem A, Kim LH, Chang K, Lum TG, Chung BH, et al. Prostate-specific antigen 10-20 ng/mL: a predictor of degree of upgrading to $\geq 8$ among patients with biopsy Gleason score 6. Investig Clin Urol 2017;58:90-7.

29. Ha YS, Yu J, Salmasi AH, Patel N, Parihar J, Singer EA, 
et al. Prostate-specific antigen density toward a better cutoff to identify better candidates for active surveillance. Urology 2014;84:365-71.

30. Oh JJ, Hong SK, Lee JK, Lee BK, Lee S, Kwon OS, et al.
Prostate-specific antigen vs prostate-specific antigen density as a predictor of upgrading in men diagnosed with Gleason 6 prostate cancer by contemporary multicore prostate biopsy. BJU Int 2012;110(11 Pt B):E494-9. 